\title{
VOID AGREEMENTS AND VOIDABLE CONTRACTS: The Need to Elucidate Ambiguities of Their Effects
}

\author{
Lantera Nadew ${ }^{*}$
}

\section{An Overview}

We enter into contractual engagements daily, if not many times a day. Every business organization, be it large or small, binds itself in bonds of contract with customers, suppliers or employees in the conduct of its business operations. All these involve interactions of contractual nature. "We all make contracts everyday... [and]... many of us spend most of our lives in performing contractual obligations." ${ }^{1}$ One may safely say that contracts are the most frequent juridical acts and the most useful among laws that govern social relationships.

However, not all contracts are valid, thereby raising the issue of defects or vices which might render the contract susceptible to invalidation, and at times of no effect. It is not, of course, possible to avoid the occurrence of vitiating factors; but we can reduce undesired effects of defective contracts. Contractants who have the necessary awareness of defective and unenforceable contracts and their subsequent effects, are unlikely to conclude defective contracts "thereby reducing risk". 2

Some defects (vices) render a contract void, while others make it voidable. ${ }^{3}$ Most legal systems expressly define defective contracts and enumerate effects that these category of contracts produce. The terms "void" and "voidable" have common law origin and are used to show the degree of defect in contract. ${ }^{4}$ Void, voidable, and unenforceable contracts denote different degrees of ineffectiveness of contractual engagement. ${ }^{5}$ These terms have their counterparts in the continental system. But under many circumstances,

\footnotetext{
* LL.B, LL.M, Lecturer and Deputy Director, | gated to shift to the right way to have fruit Institute of Federalism and Legal Studies, bearing contracts.

Ethiopian Civil Service College.

${ }^{1}$ Smith, J.C. The Law of Contracts, $2^{\text {nd }}$ ed, (London: Sweet and Maxwell, 1993) at 1

2 As careful examination of type and effects of disease is a must to prescribe a curing medicine, vices that may taint validity and legal effect of contract and the source of

such vitiating factors appears to be investi- ${ }^{5}$ Guest, supra, note 3

${ }^{3}$ Guest , A. G. (ed.) Anson's Law of Contract $26^{\text {th }}$ ed. (Oxford University Press, 1986) p. 17

${ }^{4}$ O’Donovan, Katherine , "Void and Void Marriages in Ethiopian Law" Journal of Ethiopian Law Vol. 8 No. 2 (1972) P 439
} 
the terms lack clarity and as a result usually bring about confusion and misunderstanding. ${ }^{6}$

A void contract is an act that the law holds to be no contract at all-- a nullity from the very beginning; conclusion of void contract does not change the position of "contractants." 7 They can assume as if the contract was never formed. This form of contract, therefore, cannot hold the term contract in real sense; categorizing such an empty act under contract is generally regarded as contradiction in terms. As a result, some authors prefer to use the terms "void agreement" in lieu of void contract. ${ }^{8}$ It is logically fallacious to view a void act as a contract; because if an agreement is truly void, it is not a contract. ${ }^{9}$ Strictly speaking a void contract produces no legal effect. Neither party, therefore, can sue the other for enforcement of the same. ${ }^{10}$ The defect causing a contract void is incurable and has no binding effect and hence, unless a new and independent contact is re-entered, there will be no contractual relationship. To use a statement from one of the external assessors of this article, it is absolutely impossible to kill what is already dead; a mere draft, or an "of no effect" contract cannot be invalidated.

Voidable contract, on the other hand, is binding until it is avoided (invalidated) by the option of the party whom the law protects. It is a contract,"... where one of the parties has power by manifestation of election to avoid the legal relations created by the contract ...."11 A voidable contract, thus, is a 'sick contract' that may be "cured or killed" depending upon the option that may be exercised by the victim of the defective agreement. ${ }^{12}$ That is why it is said, "Annullable acts live in a way under menace of death." ${ }^{13}$ If the victim of the vice waives his right to avoid the contract and elects to ratify it, his power of avoidance extinguishes and the contract is deemed to have had no defect from the moment of election. ${ }^{14}$

The Ethiopian Civil Code does not make use of the terms "void" and "voidable". Instead, the Code opts to employ different terminologies but

\footnotetext{
${ }^{6}$ O' Donovan, supra, note 4

${ }^{7}$ Guest , supra, note 3

${ }^{8}$ Abichandani R.K. Pollock and Mulla Indian Contract and Specific Relief Acts $11^{\text {th }}$ ed. Vol. I (Bombay: N.M. Tripathi Private Ltd ,1994), at 391

${ }^{9}$ A contract creates obligation on contracting parties. If there is no legal obligation, the relationship cannot bring about contract.

${ }^{10}$ Supra, note 3

${ }^{11}$ Morris J. (ed). Chitty on Contracts Vol. 1 (London: Sweet and Maxwell, 1972) at 15

12 An agreement may be said to be defective if it is not freely given or where the faculty of understanding of the author of consent is not developed or collapsed.

13 Planiol M. Treatise on Civil Law 12 ed. Vol. I part I (Translated by Louisiana State Law Institute, 1939) at 218

${ }^{14}$ In accordance with Art. 1811 of the Civil Code a party who is entitled to avoid a voidable contract may opt to upheld the contract whenever asked by the other party in accordance with Art. 1814 of the Civil Code.
} 
producing similar effects. ${ }^{15}$ The Civil Code has chosen to apply the expression "of no effect" whenever an agreement is intended to be null and void. ${ }^{16}$ The term voidable, on the other hand, is synonymous to the phrase, "...may be invalidated...."17

Ironically, the Ethiopian Code appears to mingle the effect of void and voidable contracts. Arts. 1808-1818 that deal with effects of defective contracts, appear to permit invalidation of a contract that is tainted with defects in object and form. Sub-art. 2 of Art. 1808 envisages that a contact whose object is unlawful or not made in a prescribed form may be invalidated at the request of any contracting party or interested third party.

It is ridiculous to talk about invalidation of a contract that is already invalid by operation of law (non-existent from the very beginning). As stated above, it is awkward to kill what is already dead. Then what is the effect of Art. 1808(2) of the Civil Code? Because of this dilemma one may be tempted to deduce that there is no difference between effects of void agreements and voidable contracts in Ethiopia. The confusion has thus created unpredictability of judgments.

Some courts, order for invalidation of contracts that were tainted with defects which can render contracts void ab initio (non-existent from the very begin-

\footnotetext{
15 Though not uniform, the Ethiopian Civil Code and the Commercial Code in some limited situations use the notion of "void" instead of the usual expression "of no effect". For instance, Art. 2828 of the Civil Code states the contract of pledge shall specify the maximum amount of money guaranteed by pledge, otherwise the contract shall be void. Art . 215 of the Commercial Code sets forth, the contract of partnership to be void if it allocates the whole profit to one partner.

16 Krzeczunowicz G. Formation of and Effects of Contracts in Ethiopian Law, (AAU, 1980) p. 57. Vices that make contracts void are specified in Arts, 1714-1716, 1719 cum 1720 (1) and subsequent provisions of the Civil Code. Contracts may be ' of no effect' where the defect relates to the object of the contract (where obligations of parties is not defined (Art. 1714) impossible (Art. 1715) or illegal (Art. 1716) the contract is of no effect. Similarly, where a form required in respect of certain contracts is not observed, the agreement cannot attain the status of

contract and remains at the draft stage for the parties are not assumed having finalized the stage of negotiation (Art. 1720(1)). Immorality of object or total lack of consent causes the same effect.

${ }^{17}$ The expression, “ may be invalidated” is set out in different provisions of the Civil Code that are meant to protect the interest of a party whose consent is vitiated or who is incapable of contracting. Contracts entered by minors beyond the power granted by law and acts of persons under judicial interdiction may be invalidated. These are persons generally regarded as incapable to enter into juridical acts and may request invalidation whenever the dealing is assumed to be injurious. Defects in consent or incapacity are the two factors that render a contract voidable.

Thus, even the words void and voidable are not directly incorporated in the general contract section like that of the Anglo-American systems. Similar concept is expressed in a different terminology but revealing almost identical consequence.
} 
ning) ${ }^{18}$ But others declare voidness of contract and order parties to be reinstituted extra contractually. In some cases the effect of period of limitation exacerbates the situation. ${ }^{19}$

This short article attempts to shade light on effects of void agreements and voidable contracts under the Ethiopian Civil Code. The possible and actual confusion that frequently arises because of the uncertainty of terms will be briefly assessed and possible ways out will be pointed out. The effect of period of limitation on void agreements has been a confusing issue, and an attempt has been made to propose possible solutions until a binding authoritative interpretation is rendered through a decision of the Cassation Division of the Federal Supreme Court or until a remedial legislative action is taken.

\section{The Nature of Defective Contracts}

Defective contracts are contracts which do not satisfy the essential elements that are necessary to have a valid contract. ${ }^{20}$ Deficiency pertaining to some of the elements makes a contract voidable and others cause it to be void (to be non-existent or of no effect). Defects relating to capacity and consent make a contract voidable. $^{21}$ An incapable person is a person who is protected by law from possible contractual abuses and may opt either to 'kill or cure' the contract. The option usually depends upon fruits of the contract. If the contract is assumed to be fruitful, the person may not opt to invalidate it. ${ }^{22}$ In this case, the dealing remains valid and the defect is regarded as cleansed. The effect

\footnotetext{
${ }^{18}$ Facts of the Cases are mentioned in Part III.

${ }^{19}$ Interested third parties or contracts usually demand invalidation of void contracts because of the confusion resulting from the wording of Art. 1808(2) of the Civil Code.

${ }^{20}$ Art. 1678 of the Civil Code enumerates the essentials of contract. Lack of some of these elements causes a contract to be non-existent from the very beginning and others make it merely defective but enforceable.

${ }^{21}$ Art. 1808(1) of the Civil Code.

${ }^{22}$ Art. 1808(1) of the Civil Code With regard to juridical acts entered by minors, Art. 299 of the Revised Family Code (Federal Negarit Gazetta Extraordinary Issue No. 1/2000) uses the expression of no effects. Sometimes the Code uses the word may be annulled or annullable. The wording of Art. 299 of the Civil Code may create an impression that contracts entered by minors are void. But the intention of the lawmaker is manifested in

Art. 1808(1)of the Civil Code . Art. 300 of the Revised Family Code, for example, declares that the nullity of juridical acts entered by minors may be demanded by the minor, his/her heirs or representatives. Where the fruit of the dealing is assumed beneficial these people may not request for invalidation and hence the contract will remain valid. The drafter was not selective in using terms when drafting the Code. This failure can be remedied by resorting to other provisions of the Civil Code. The legal effect of juridical acts performed by a person under judicial interdiction and minors is identical (Art. 358 of the Civil Code). Art 387 of the Civil Code defines instances in which a person interdicted by law may demand invalidation of juridical acts. As per this provision the interdicted person, the person who dealt with him/her or the public prosecutor can request for invalidation.
} 
of defective consent is also the same. ${ }^{23}$ The victim of consent may decide to avoid or confirm the transaction. Unless the person exercises the option, the law does not avoid effects of the contractual dealing.

Strict application of the literal reading of the beginning phrase in Art. 1678 of the Code is true with regard to defect pertaining to object and form of a contract. $^{24}$ Lack of object ${ }^{25}$, ambiguous object, impossible or illegal object makes the agreement of no effect. ${ }^{26}$ Similarly, non-compliance with the form required by law or prescribed by the contracting parties makes the contract non-existent from the very beginning (void $a b$ intitio). ${ }^{27}$ The old maxim "forma dat esse rei" ${ }^{28}$ ( form gives existence to the transaction) envisages the

\footnotetext{
${ }^{23}$ Arts $1696-17710$ of the Civil Code define the effects of contracts tainted with vices of consent. Consent is one of the pillars in contract. Consent to produce contract has to be sustainable at law. This means, it has to be freely given. If consent is tainted by mistake, fraud, duress or other cases of undue influence it is said not free and not sustainable at law. In this case, the victim of the defective consent can require invalidation of the contract.

${ }^{24}$ Art. 1678 of the Civil Code begins with the expression, "No valid contract shall exist unless---"“ This expression seems making the effect of lack of capacity and defective consent almost identical with the defect in object and form of contract. This assumption is far away from the intention of the lawmaker. The intention of the lawmaker is evident from various provisions that deal with effects of defect in capacity and consent. See for example Arts. 1696 - 1710 of the Civil Code with regard to effects of defective consent and Art. 1808(1) and other provisions defining effects of contractual dealings of an incapable person. After all, the law has devised the possibility of invalidation to protect an incapable person. Children below the age of 18 are regarded as incapable because their faculty of understanding is not developed. The faculty of understanding of insane persons and persons under judicial interdiction is supposed collapsed. The defect in faculty of understanding calls for legal protection. The law is assumed standing at the side of these people and favors them. This category of people

can request for invalidation unless the right is barred by period of limitation. On the other hand, Arts. 1714-1716 of the Civil Code specify effects of contracts the object of which is defective. Similarly, Art. 1720 of the Civil Code declare the effect of nonobservance of formality requirement.

${ }^{25}$ By object we mean the obligations of contracting parties. Contracting parties promise to discharge certain obligations to their contractant. The promise of each of the contracting parties becomes their respective obligation.

${ }^{26}$ Arts. $1714-1717$ of the Civil Code.

${ }^{27}$ The term "form" is not defined in the Code. It is the solemnity that the law attaches to a contract. Some times the law requires a contract to be made in writing. In certain situations, the law demands a written contract to be registered. The Commercial Code, for example, demands partnership agreements to be made in writing and be registered. Registration therefore, may be taken as a formality requirement. Copies of all written documents have to be deposited. Deposit of contractual documents may also be taken as a formality. Arts. 1721 -1725 declare general situations that require attestation. All written contracts shall be attested by two witnesses. Thus, attestation is a formality requirement. Similarly, Arts. 1728 to 30 make signature of contracting parties as a formality requirement. As stated in Article 1726 contract parties may also prescribe a given kind of formality other than those mentioned in the Civil or Commercial Code. ${ }^{28}$ Planiol, supra, note 13 at 233
} 
effect of non observance of 'the Form' requirement. Thus, "the ... solemn form which the law exacts for certain acts is generally considered to be a cause for their existence." ${ }^{29}$ If contracting parties enter into a contract ignoring the form prescribed either by law or agreed by the contracting parties, the act is deemed not to have been made. ${ }^{30}$ Art. 1720 of the Code reads "where a special form is prescribed by law and not observed, there shall be no contract but a mere draft of contract." The mere draft is not a contract but a simple intention to enter into a contract. It can, thus, be ignored by any contracting party or third party.

However, if the departure of formality requirement relates to some ancillary matters such as stamp- duty, registration fee or even non-compliance of requirement of publicity, unless otherwise clearly stated, the effect of such trifle violation does not render a contract void $a b$ initio, and the contract remains valid ${ }^{31}$ subject to the requirement that the formalities which are lacking ought to be fulfilled if the instrument is to be produced as evidence for the existence of a binding contract.

\section{Invalidation and Declaration of Voidness}

Invalidation is the process of setting aside a defective contract. Vices that render contracts to be invalidated are mentioned in Art. 1696 and 1808 of the Civil Code. Art. 1696 of the Code states, "A contract may be invalidated where a party gives his consent by mistake or under deceit or duress". To have a valid contract-a contract that binds all of the contracting parties-- the law requires, not a bare consent but a consent that is freely given. If one consents to an act with a vitiated consent, ${ }^{32}$ the law permits him/her either to 'kill or cure' the contract weighing fruits it may generate. Similarly, where a party to the contract is incompetent (i.e. lacks capacity due to age, mental condition, etc) to conclude a valid juridical act or acts beyond his/her authority, the contract may be avoided depending upon the option to get rid of the act. $^{33}$

${ }^{29}$ Ibid
${ }^{30}$ Art. 1720(1) of the Civil Code.
${ }^{31}$ With regard to authentication, Gorfe G/
hiwot vs. Aberash Dubarge et al (Cassation
File No. 21448) is very notorious and has
been an issue of current legal discussion.
The main theme of this case is that an unau-
thenticated contract of sale of an immovable
property cannot produce legal effect. Before
disposition of this case, failure to have a
contract authenticated was not considered as
a factor causing a contact to be of no effect
but now it has been a settled rule and au- thentication has been one of the formality requirements for legality of a contract relating to immovable property.

${ }^{32}$ Needless to say, a person may consent to an act because of mistake, fraud, duress and other cases of undue influence. Vices of consent are specified from Art. 1696 -1710 of the Civil Code. Instances in which a contract may be invalidated, the meaning of vices and requirements that have to be met to invoke each of the vices are specified in the Civil Code.

${ }^{33}$ Art. 314 of the Civil Code. 
Contractual engagement of a minor may be impugned by the minor when he/ she develops the faculty of understanding to weigh the fruits of contract, or by his/her representatives or heirs just after conclusion of the contract. The condition of notoriously insane or persons under judicial interdiction is not different. The law guards such persons with lessened capacity from 'dangerous juridical acts'. This category of people should not be exploited under the guise of contract. Contractual dealings of persons who have failed to understand the effect of their act may be impugned at the request of the insane or interdicted person or by their representatives or heirs. ${ }^{34}$

As stated in the Civil Code (Art. 387) juridical acts entered into by persons under legal interdiction may be invalidated. Article 387 of the Civil Code declares that "Juridical acts performed by a person interdicted by law in excess of his power shall be of no effect." ${ }^{35}$ The expression, "of no effect" in the sense of Article 387 seems to mean voidable. This meaning is very evident from the words used in the Amharic version of the Code. Sub art. 2 of Article 387 of the English version permits nullity of acts performed by an interdicted person at the request of certain specified persons. If anyone of these persons fails to demand nullity of the act, the act would remain valid. Can we conclude that juridical acts performed by persons under legal interdiction are void ab intio? We don't have to be guided by the expression "of no effect" in this case, as the same expression is used with regard to juridical acts performed by minors (Art. 299 of the Revised Family Code). ${ }^{36}$

A contract at the menace of invalidation (voidable contract), thus, is a contract that is defective (but binding) from its very inception, and it may or

\footnotetext{
${ }^{34}$ Art. 343 of the Civil Code: An insane person to require invalidation of a contract while his/her faculty of understanding was collapsed should prove the fact that he/she was not in a lucid period. He/she may be required to produce evidence that he/she did not understand the effect of the contract at the critical time that he/she has entered into the contract. Proving the mental state of a person is possible but not simple to understand owing to the current Ethiopian condition. To protect the interest of the person who frequently fails to understand effect of juridical acts, it is advised to have judicial interdiction.

${ }^{35}$ Civil rights of an interdicted person may be restricted because of his dangerous nature. Acts that may be freely performed by a per-
}

son under legal interdiction are enumerated in Art. 386 of the Code but no reference is made to contracts. Using the principle of ejusdem generic or interperetetio restricta) it is possible to reach at the conclusion that a legally interdicted person cannot enter into a contract free from defect if he/she concludes beyond his legal power, the contract is susceptible to death.

${ }^{36}$ The English version of the Civil Code does not explicitly mention whether contracts entered by persons under legal interdiction may be invalidated. The Amharic version, however, avoids the uncertainty and expresses that contracts entered by persons who are interdicted by law may be invalidated. A person may repetitively commit a crime relating to contracts. (cont.) 
may not be invalidated at the option of party entitled to do so. This means, the contract is not a nullity from the beginning, and , it is valid and binding until it is rescinded. ${ }^{37}$ The party whose consent is vitiated or who is regarded as incompetent of concluding juridical acts has two options: he/she can seek invalidation or ratify it where the act is considered fruitful. If he/she chooses to adopt the contract, the power of avoidance would be extinguished and the contract will be deemed to have had no defect. ${ }^{38}$ Even if he/she opts to invalidate the contract, the other party can avoid invalidation if he/she agrees to make the deficiency good. ${ }^{39}$

Arts. 1808-1818 of the Code are meant to regulate the effects of invalidation of voidable contracts and effects of void contracts. Art 1808 (1) of the Civil Code specifies the two categories of defects that can render a contract voidable. $^{40}$ This provision is in line with the definition of voidable contracts. However, Art.1808 (2) of the Code is the source of all the confusion as it seems to allow invalidation of void contracts. ${ }^{41}$

${ }^{36}$ (cont.) To reform the person and save the public from the dangerous behaviour of the criminal the court while passing criminal judgement may interdict the person by making prohibition. In this case one may, however, query whether the interdiction is made to protect the person and the choice of invalidation has to be decided by the interdicted person or whether it is imposed to punish the criminal. If the former reason is true, it is possible to argue that a contract entered by a person under legal interdiction is voidable and may be declared void by the request of the interdicted person if the fruit of the contract is assumed to be injurious. But if the later case is taken as a reason for interdiction, obviously, the contract would be taken as illegal and void $a b$ initio. If the person is interdicted, he/she may be reformed and the prohibitive adjudication may be said to be beneficial. But the faculty of understanding of a person under legal interdiction is neither collapsed nor less developed. An interdicted person knows what he/ she does. Sub art. 2 of Art. 387 fuels the perplexity. It states that "The nullity thereof may be required by the interdicted person, the person with whom he has contracted or the public prosecutor though the subject matter of the act performed were illicit.
This leads to question whether legal interdiction causes contracts to be void or voidable. If the contract is merely taken as void, the agreement cannot produce legal effect and no need for invalidation. If it is taken as merely voidable, the right person that can demand invalidation of the contract is the interdicted person or persons acting on his/ her behalf. The Code, however, permits invalidation of contracts by the other contracting party too or by the public prosecutor. This is the future of void contract and it is possible to argue that contracts entered by persons interdicted by law are void in spite of the usual words of nullity or the clear expression of the Amharic version.

${ }^{37}$ Guest, supra, note 3 at 18

${ }^{38}$ Art. 1811 of the Civil Code.

${ }^{39}$ Art. 1702(2) of the Civil Code, Art. 1812 of the Civil Code.

${ }^{40}$ These are already pointed out above with regard to vitiation of consent and incapacity of parties

${ }^{41}$ Art. 1808(2) of the Civil Code states that "A contract whose object is unlawful or immoral or a contract that is not made in a prescribed form may be invalidated at the request of any contracting party or interested third party" 
As has been pointed out, the defect in void contracts is not curable. It is a permanent defect. How can courts give life to an illegal act or an act that is not made in a prescribed form? In Ethiopia, courts do not have a power to change legislative enactment or challenge its effect. ${ }^{42}$ It has been mentioned above that because of this confusion which emanates from the wordings of Sub-art. 2 of Article 1808 of the Civil Code, some lower courts have rendered decisions which validate contracts that were tainted with incurable defects. $^{43}$

In the case, Askale Tesema vs. Setegn Getahun and Asfaw Banti, ${ }^{44}$ the first defendant sold a residential house that belonged to the plaintiff and to the second defendant without acquiring her consent while the plaintiff was in separation. The contract was concluded in writing but was not registered. After lapse of the required time, the plaintiff demanded invalidation of the contract. The Federal First Instance Court accepted the defence of period of limitation. The present plaintiff appealed against this decision. The Appellate Court decided that the contract did not fulfil the requirements of the law, and found that the case is thus imprescriptible. The Court relied on Art. 1723 of the Civil Code. ${ }^{45}$ The effect of failure to comply with a form prescribed by law or by contracting parties is provided in Article 1720 of the Civil Code. ${ }^{46}$ The Court concluded that as the parties have not observed the prescribed form - the requirement of registration, there shall be no contract. Consequently, the Appellant's right cannot be barred by the period of limitation. The Court decided that where there was no contract, the right cannot be barred either by the general period of limitation that is envisaged in Art. 1845 of the Civil Code or under the specific stipulation of Article 1810. The Court further concluded that where there is no contract, provisions dealing with the effects of invalidation of contracts cannot govern a non-contractual relationship and it ordered parties to be reinstated extra contractually.

\footnotetext{
${ }^{42}$ It has been pointed out above that currently Cassation Division of five judges is empowered to ascertain recurring legal confusion and taken as a law binding all the lower court including State courts.

43 These courts argued that if request for invalidation is not brought within the requisite time for invalidation in accordance with Art. 1810 or 1845 of the Civil Code, the contract cannot be invalidated. This means that the contract will remain valid and enforceable in court of law. Moreover, claimants demand invalidation of the contract citing Art. 1808 (2) of the Civil Code. This kind of decision is usually quashed by higher courts. This is

waste of time and resource and has to be managed in accordance with the spirit of the law.

${ }^{44}$ Civil Appeal №. 1470 Federal High Court Addis Ababa, (Archives), Erasho Bagage vs. Getahun Bololo, Civil Case №. 1/88 Bolose Woreda Court (Archives)

${ }^{45}$ Art. 1723 of the Civil Code requires a contract relating to immovable properties to be made in writing and be registered in court or notary. .

${ }^{46}$ As stated in this provision, if a contract is not entered in a prescribed form, the agreement cannot be taken as a contract but remains at the stage of negotiation - a draft. .
} 
The purpose of this short article is not to comment on the disposition of the case but it appears important to note whether the Court's decision was in the right direction. The lower Court purely based its judgement on Art. 1808(2) cum 1810 of the Civil Code and decided that the right to bring action for invalidation is barred by period of limitation. It is true that Art. 1810 of the Civil Code requires an action for invalidation to be brought before an appropriate court within two years. The commencement of the period varies depending upon the moment that the vice disappears. ${ }^{47}$ If Art. 1808 (2) were applicable to govern invalidation of a contract with defective object or failure to comply with a requisite form, the decision of the lower Court would have been correct. But permitting invalidation of a contract tainted with defect in object or form makes Articles 1714 -1716 and 1719 - 1730 of the Civil Code superfluous. The intention of the lawmaker that is revealed in these provisions cannot easily be defeated by a single sub-provision. The apparent contradiction by the aforementioned provisions and Article 1808(2) needs to be settled by judicial construction or legislative action. One of the basic rules of statutory interpretation is that whenever the strict literal reading of a given legal provision is absurd, unreasonable or inconsistent with other provisions, interpretation is necessary despite a seemingly clear reading of the provision. Under such circumstances, resort shall be made to the function, spirit and purpose of the provision rather than its rigid literal reading.

In Askale Tessema vs. Setegne Getahun and Asfaw Banti ${ }^{48}$, the Appellate Court affirmed that a non-registered contract is void. Arts. 1723 and 1720(1) of the Civil Code lead to this conclusion but this assertion at the time was not in line with the purposes of registration. ${ }^{49}$ The purpose of registration, as stated in the Civil Code, is creating public notice (constructive notice). The part of the Civil Code that was meant to regulate the process of registration of immovable properties in Ethiopia is still under suspension and the guiding rules are customary rules that were being used before the coming into effect

\footnotetext{
${ }^{47}$ A brief discussion on period of limitation in general and the relationship between Art. 1810 and 1845 is summarized under Part IV below. .

${ }^{48}$ Supra, note 44

${ }^{49}$ Currently there is a hot discussion among the lawyers concerning the effect of registration in Ethiopia. Some view that the disposition of Gorfe G/hiwot vs. Aberash Dubarge et al has changed the effect of registration from ad probationem to ad validitatem. Careful looking of the Case reveals that the focus of the Case is on authentication but not on registration. If this holds true, it is

possible to argue that the purpose of registration is not changed and its purpose is only to create constructive notice among the public. Authentication has to be conducted in the Office of Registration of contracts and registration of contracts involving immovable properties has to be carried out in municipalities as it was being done customarily. See also Art. 3364 of the Civil Code. For detailed discussion on this issue see Kassa Nakumo (Fitawurar) vs. Akililu Gobeze, Civil Appeal No. 353/57, and Supreme Imperial Court Div. No 1, Journal of Ethiopian Laws, Vol. IV No. 1 at 69.
} 
of the Civil Code of $1960 .{ }^{50}$ Art. 3364 of the Civil Code declares that, "The customary rules relating to the formalities to be complied with so that the transfer or extinction of the ownership of immovable properties may be set up against third parties shall apply." Before the enactment of the Civil Code of 1960, customarily, transactions involving immovable properties were being registered in the rist section of municipalities. ${ }^{51}$ As revealed in Article 2878 of the Civil Code, registration of contracts serves as creating public awareness as to the facts of registered contracts. This means unregistered contracts relating to immovable properties cannot affect the interest of third party but valid among the contracting parties. ${ }^{52}$

In Askale Tessema vs. Setegn Getahun and Asfaw Banti, it is not doubtful that the plaintiff is not a contracting party and hence the contract cannot affect her interest, as it was not registered. What is then the legal effect of this contract? As W/ro Askale can regard the contract as if it was never concluded, there is no need to require invalidation of contract. The causes of invalidation of a contract are not manifested in this contract. ${ }^{53}$

The decision of the lower court therefore seems to be erroneous. On the other hand, the Appellate Court seems to have gone to the other extreme. Failure to have a contract registered, at the time, cannot be taken as a factor which renders the contract of no effect. The Appellant demanded invalidation of the contract because of the express wordings of Art. 1808(2) of the Civil Code. But she had no obligation to do so, as unregistered contract relating to sale of the building cannot affect her interest. Then one may query the action that could have been taken by W/ro Askale. While her house was being held by a person under the guise of a defective contract, her motive is to get rid of the injurious contract and she had no option other than invoking Article 1808(2) of the Civil Code. W/ro Askale used the wording of the Code as it is and demanded invalidation of the contract. The second Respondent, Ato Asfaw had

\footnotetext{
${ }^{50}$ Art. 3363 cum 3364 of the Civil Code.

51 Kassa Nakumo (Fitawurari) vs. Akililu Gobeze, Civil Appeal No. 353/57, Supreme Imperial Court Div. No 1, Journal of Ethiopian Law, Vol. IV No. 1. at 69

${ }^{52}$ Before the incorporation of European Communities law, in England, the purpose of registration was similar to the Ethiopian stand. Later on, the English law gave protection only to innocent third parties. In this case a party knowledgeable as to the contract cannot be protected. This means, a third party having awareness as to the unregistered contract cannot be guarded.
}

(Unregistered contract may affect the interest of third parties that have awareness as to the contract). The Ethiopian law is silent in this regard. It is, therefore, possible to argue that where a contract relating to immovable properties is not registered, third parties are generally protected. (The contract cannot be enforced against the interest of third parties.

${ }^{53}$ In this particular case, the causes that render a contract to be invalidated are not prevalent and hence the plea of invalidation is not relevant. The plaintiff is entitled by law to regard as if the contract was never concluded. 
to invoke Article 1810 to avoid invalidation of the contract. Had the Plaintiff in the lower court demanded declaration of voidness rather than invalidation, as this expression is not specified in Art. 1810 of the Civil Code, probably the defendant would not have invoked the defence of period of limitation or the Court would not have accepted the defence.

If a contract is void, anyone of the parties may refuse performance and may not necessarily petition for declaration of voidness. However, in certain limited instances the demand for declaration of voidness appears to be imperative. W/ro Askale's case falls under the latter scenario. Unless she demands declaration of voidness how can she avoid the effect of the contract as the "purchaser" holds the building and got evidence disclosing the fact that he had purchased the house. In some cases, parties may not agree on the voidness of the contract and may demand for enforcement of the agreement. In this case too, the contracting party or any interested third party may apply for declaration of voidness and call for restitution. For purpose of restoration to the former position (to the position that contracting parties were before the formation of the contract), Arts. $1808-1818$ is relevant. The court cannot lend its hand for enforcement of a void transaction; however, it can assist towards the avoidance of effects of defective dealing.

In some legal systems, if a contract is void the court need not order for restitution. In English law, for example, a contract for gaming and gambling is void and the court cannot assist for restoration to the former position. ${ }^{54}$ In Ethiopia, however, as the part of the Code governing restitution does make distinction, where a contract is declared void, things that were given or delivered under the guise of contract should be returned back.

Now the question whether the petition for declaration of voidness may be barred by lapse of time is outstanding and will be addressed in the next part.

\section{Period to set aside Defective Contracts}

Voidable contracts cannot keep going in a defective condition perpetually. If the defective nature is discovered by contracting parties or interested third party having right to annul the contract, the defect should be avoided by the process of invalidation. The victim of defect may also opt to ratify the defective dealing. Ratification cleanses the contract from the defect. If the victim of defect opts to invalidate the contract, he/she should exercise his/her option within the period prescribed by law. Where the defect is of a nature that entitles the victim to request for the invalidation of the contract and if a party does not exercise his/her right within the time stipulated, the law cleanses the contract.

\footnotetext{
${ }^{54}$ Guest, supra, note 3 at. 7
} 
A period for setting aside of defective contracts in Ethiopia is another area of ambiguity and has been subject of litigation in courts. The effect of period of limitation of void contracts is not simple as it may seem because of the arduous task of distinguishing the two categories of defective contracts. Decisions are not uniform in this regard. In the case Tirunesh Dadi vs. Abebech Lendado, ${ }^{55}$ the lower court held that the period of limitation had run to invalidate the contract, because 3 years had passed from the date of conclusion of the contract. This judgment was quashed by the Appellate Court. The Appellate Court ruled that an illegal contract cannot be maintained by invoking lapse of time. The Appellate Court summed that mere lapse of time cannot validate an illegal contract and hence a void contract can be challenged at any time. A similar decision was rendered in the case Askale Tesema vs. Setegne Getahun and Asfaw Banti. ${ }^{56}$

In Erasho Bagaje vs. Getahun Bololo ${ }^{57}$ an agricultural land was sold to the defendant. After lapse of three years of the transaction, the plaintiff demanded invalidation of the contract pursuant to Art. 1808(2) of the Civil Code. But the court declared voidness of the contract ignoring the wordings of Art. 1808(2) of the Civil Code. The Court asserted that sale of land is unlawful pursuant to Art. 1716 of the Civil Code and ordered the buyer to restore the land. The seller was ordered to refund the purchase price of Birr 3000 and got the land back.

The Code sets forth two provisions which govern the time for invalidation of contracts. First, the general period of limitation that is enshrined in Art. 1845 and the other is embodied in Art. 1810(1). There seems to be apparent redundancy and hence clarifying a "grey area" appears to be imperative to resolve the prevailing uncertainty. To comprehend the effect of period of limitation (limitation of action) on defective contracts and thereby avoid or reduce the confusion, let us first deal with the general nature and effect of period of limitation (limitation of actions).

\section{1- The Nature of Period of Limitation}

A period of limitation is a procedure that limits the time within which an action shall be brought. It is a time limit at the end of which an action may not be entertained in courts of law. ${ }^{58}$ After lapse of a period within which action has to be lodged, no remedy may be granted in courts of Law. In early Ro-

\footnotetext{
${ }^{55}$ Civil Appeal No. 35/87, Wolaita Zone High ${ }^{57}$ Civil Case No. 1/88 Boloso Woreda Court , Court (Archives) Areka ( Archives)

56 Civil Appeal No 1470/84 Federal High ${ }^{58}$ Corpus Juris Secundum, Limitation of AcCourt (Archives) tions Vol. 53 (New York: American Law Books Co, 1948) at 900
} 
man law there was no period of limitation and actions were perpetual. A debtor could not thus defend himself by invoking lapse of time in action, no matter how long it was. ${ }^{59}$ It was at a later stage that the Imperial Constitution established a means of defence against perpetual actions. ${ }^{60}$

Today, in all legal systems, rights should be exercised within a defined period of time after which the law stands at the side of the defendant and prohibits a stale claim. The time limit for bringing action need not be alike in all legal systems. For example, in France, the longest period of limitation for personal as well as real actions is thirty years ${ }^{61}$. In Philippines, according to Art. 1149 of the Civil Code, general period of limitation is 5 years. ${ }^{62}$

A claim neglected for many years without any attempt to enforce it creates a presumption that it has ceased to exist. ${ }^{63}$ The recognition of period of limitation is based on two assumptions. ${ }^{64}$ First, a reasonable delay in presenting a claim may place the other party at a serious disadvantage since evidence may be lost. Secondly, lapse of time may be regarded as evidence for tacit abandonment of claim. Where a creditor remains too long without requiring payment, for example, the law takes away his/her right of action, as a claim that is neglected for many years without any attempt to enforce creates a presumption that it has ceased to exist. ${ }^{65}$

In Doughlas v Lioyd's Bank Ltd ${ }^{66}$ (1886), the deceased ("F") had deposited a large sum of money with the defendant bank on terms that he could withdraw at any time giving 14 days notice. "F" died before withdrawing the money. After 61 years, (in 1947) his heirs presented deposit receipt and demanded

\begin{tabular}{|c|c|}
\hline $\begin{array}{l}{ }^{59} \text { Ibid } \\
\text { Planiol supra, note } 13 \text { at } 579 \text {. In Ethiopia, } \\
\text { too, before Fetha Negast, actions were per- } \\
\text { petual. Fetha Negast declared the time at } \\
\text { which actions to be brought before court of } \\
\text { law. This law provided that if some one has } \\
\text { left any thing belonging to him with another } \\
\text { person for a period of thirty years and he has } \\
\text { not asked for it, cannot claim it after the } \\
\text { expiration of this period nor can his son. The } \\
\text { same principle applied for debts, inheri- } \\
\text { tance, fraud etc. After lapse of this time, no } \\
\text { remedy was provided. ( see Paulos Tsadua } \\
\text { (Abba), Fetha Negast, ( Law Faculty, AAU, } \\
1968 \text { p. Xvi) } \\
61 \text { Planiol supra, note } 13 \\
62 \text { David Rene, Commentary on Contracts in } \\
\text { Ethiopia, (translated by Michael Kindred } \\
1973 \text { ) page } 89 \text {; some jurisdictions fix ten } \\
\text { years as that of the Ethiopian system. Art. }\end{array}$ & $\begin{array}{l}127 \text { of the Switzerland Code of Obligation, } \\
\text { Art. } 167 \text { of Japanese Code, Art. } 349 \text { of } \\
\text { Lebanon, Art. } 2946 \text { of Italian Civil Code. } \\
\text { The drafter of the Civil Code submits that } \\
\text { the Ethiopian formula is taken from the Ital- } \\
\text { ian Civil Code. Art. } 374 \text { of the Egyptian } \\
\text { Civil Code declares } 15 \text { years, Article } 249 \text { of } \\
\text { the Greek Civil Code provides for } 20 \text { years. } \\
\text { BGB Section } 195 \text { sets the maximum period } \\
\text { of limitation } 30 \text { years as that of the French } \\
\text { Code. } \\
63 \text { Corpus Juris Secundum, supra, note } 60 \text { at } \\
901 \\
64 \text { Ibid } \\
65 \text { Paton W.C. A Text Book of Jurisprudence } \\
13^{\text {th }} \text { ed. (Oxford University Press, 1964) at } \\
45 \\
66 \text { Doughlas vs. Lloyd's Bank Ltd. 34 Comp. } \\
\text { Case } 263\end{array}$ \\
\hline
\end{tabular}


the money. At the time the bank had no records for the deposit. The claimants instituted action against the bank for its failure to allow withdrawal of the money. It was held that under circumstances of such extraordinarily long lapse of time and in the absence of all relevant evidences regarding deposit in current account, the bank was not obliged to pay.

The rule of period of limitation is important and safeguards public interest in many respects. First, it reducers burden of courts by restricting certain neglected claims. And, when time goes on, truth may be forgotten as human memory may fade, witnesses may die or evidences may be lost -- the nearer the action into the ken of events, the easier to discover the truth. ${ }^{67}$ If evidences supporting or disproving the claim are lost, or facts of the case have disappeared from minds of people, innocent persons may be exposed to fraudulent claims.

The importance and necessity of period of limitation is never doubted. A learned judge remarks: “... statute of limitation is a statute of repose, peace, and justice. It is one of the repose because it extinguishes stale demands and quite title. ... controversies are restricted to a fixed period of time least they should become immortal while men are mortal. It secures peace as it ensures security of right; and it secures justice as by lapse of time evidence in support of rights may have been destroyed."68

It is generally accepted that the doctrine of period of limitation is a defence that may bar procedural rights. However, the rule of period of limitation does not go to the extent of affecting substantive rights. One may thus question the importance of a dormant right - a right that cannot be enforced in court of law. There are limited instances in which a dormant right may be active. The holder of a dormant right may enforce it in tribunals other than formal courts if the debtor consents to litigate.

In exceptional cases, the court may also permit enforcement of a right barred by period of limitation. As revealed in Art. 2199(2) of the Civil Code, where a defective thing was sold and the purchaser failed to bring action within one year of notification of a defect, the purchaser can demand set off if the seller sues for unpaid balance of price. On the same token, if the defence of period of limitation is not raised as a preliminary objection, the holder of a stale right can still proceed in court of law.

\footnotetext{
${ }^{67}$ Sethi D. Basu's Limitation Act $4^{\text {th }}$ ed. (Law ${ }^{68}$ Bhatnagar J. Parkash, Commentary on the Book Co. Allahabad, 1972) at 1. Limitation Act (Eastern Book Co. Lucknow, 1964) at 12




\section{2- Period of Limitation vis-à-vis Voidable Contracts}

The right to avoid a defective contract can only be enforced if it is claimed within the time fixed by law. It is repeatedly mentioned that the law makes an act voidable with the intention to empower a weak party - a party protected by law - to avoid the effects of the contract provided that the request for invalidation is lodged in due time. If the party that is entitled to avoid the contract doesn't do so within the time limit prescribed by the Code, the law takes away the shield and cleanses the defect automatically under the assumption that the party who is protected by law has waived his right or has ratified the act.

With regard to invalidation of voidable contracts, the Civil Code has provided two provisions. Although Art. 1810 of the Civil Code is the first provision that has to be considered for issues involving period of limitation regarding invalidation of defective contracts, there are instances that Art. 1845 of the Civil Code may regulate the situation. Art. 1845 of the Civil Code is a general provision governing issues of limitation of actions involving all cases of contracts. ${ }^{69}$ It provides that "Action for invalidation, performance or nonperformance shall be brought within ten years." Art 1810 (1), on the other hand, reads: "No contract shall be invalidated unless an action to this effect is brought within two years from the ground for invalidation having disappeared."

Upon first impression, one may be confused by the two regulatory provisions (Arts. $1845 \& 1810$ ) for both of them deal with the issue of invalidation of defective contracts but with different time limits. How can we reconcile the two provisions? What would happen if a person seeks invalidation of a voidable contract after 9 years of the disappearance of the fact that rendered the contract voidable? Would it be possible to invalidate a voidable contract that was tainted by a defect that was discovered after 13 years of formation of the contract? If a vitiating factor that entitles the victim to seek invalidation is discovered, such party should not keep silent for unwarranted period of time. Art. 1810 requires that the option to avoid a defective contract be exercised within two years from the date of awareness of the defective state of the contract. If the victim of defect fails to bring action within two years, the law cleanses the contract from defect and the victim may not be allowed to sue his/her contractant. What would happen if the victim becomes unable to sense the "pain" of the vice and fails to bring action before lapse of ten years from the date of formation of the defective contract?

${ }^{69}$ Art. 1845 of the Civil Code governs all issue including invalidation, performance, nonperformance of contracts. 
If the cause for invalidation disappears in less than ten years, the governing provision is Art. 1810 of the Civil Code. After disappearance of the cause, the victim is expected to demand invalidation of the defective contract within two years provided that the maximum time cannot exceed 10 years. Art. 1845 of the Civil Code does not permit invalidation of a defective contract to be sought after lapse of ten years. This is the maximum period of limitation that can apply. In the case of unconscionable contracts or lesion (Art. 1710), however, the period commences from the date of the conclusion of the contract (Art. 1810/2). In this case, the victim of vice enters into the contract with full awareness of the defective nature of the contract and is expected to bring action for invalidation within two years of the conclusion of the defective contract.

\section{3- Period of Limitation vis-à-vis Void Contracts}

It has been pointed out that a void contract generates neither right nor duty to be enforced in court of law. The issue of period of limitation cannot thus be invoked where there is no right. As discussed earlier, period of limitation is simply a procedural device that bars a right if it is not exercised within a defined period. "Because of the fact that defect of void or nonexistent contract is more or less a permanent character, mere lapse of time cannot give efficacy to such contracts."70 Planiol shares the same view saying : " nullity is imprescriptible" ${ }^{71}$ It makes no sense for lapse of time to make an act efficacious when it was forbidden by law. However old it might be, a void act can produce no effect. Therefore, the rules embodied in Articles 1810 and 1845 are not relevant to void contracts.

In many cases, however, victims of void contracts demand invalidation of contract and most lower courts tend to give decisions on the basis of Art. 1808(2) and Art. 1810 of the Civil Code. As observed in the case, Trunesh bandi $v$. Abebech Lendado, the defendant requested for invalidation of the contract and the lower court accepted the defence of period of limitation with the intention of cleansing the defect of illegality. The lower court in the case Askale Tesema vs. Setegn Getahun and Asfaw Banti followed the same direction.

Attempt has been made to show that a void contract is not subject to period of limitation. The usual question involving period of limitation vis-à-vis void acts is: what would happen if contractants fail to agree on the status of the

\footnotetext{
${ }^{70}$ Jurado Desiderio P. Commentary and Juris- ${ }^{71}$ Planiol, supra, note 13 prudence on Obligations and Contracts, Rev. ed. (Coloocan City: Phillippine Graphic Arts Inc, 1969) at 483 - 484
} 
contract? It is also questionable whether a contracting party or interested third party can request invalidation of a void contract by invoking Article 1808(2) of the Civil Code. If enforcement or invalidation of a void contract is sought by any of the two contracting parties or interested third parties, the court may order for declaration of voidness of the contract even if it is not requested by the parties. Declaration of voidness is a judicial decision which declares that there is no contract between the claimants. The parties, therefore, have to be restored to the former position by the process of restitution (Arts. 1815-1818). However, in Askale Tesema v. Setegne Getahun and Asfaw Banti, the High Court, after declaring voidness of the contract, ordered for restitution extra-contractually. The Court based its argument on the nature of the void contract. As there was no contract, restitution provisions of the Civil Code were assumed not applicable. Where parties have attempted to conclude a contract and the agreement failed to produce contract, restitution should be effected on the basis of Arts. 1815 - 1818 of the Civil Code. ${ }^{72}$

\section{Conclusion}

Where dispute arises regarding the status of void contracts, courts may declare voidness of the contract. It is to be noted that declaratory judgement of voidness may be given at any time without the need to comply with the requirement of period of limitations. Declaratory judgement of voidness cannot be stale and passage of time cannot cleanse the defect that vitiated the contract. As a void contract is an act inexistent in eyes of law, it is apparently imprescriptible. This is so, as opposed to voidable contracts where an option to invalidate the contract should be exercised within two years from the date of disappearance of causes rendering the contract defective. It must, meanwhile, be noted that the right to demand invalidation of a voidable contract cannot go beyond the maximum period of limitation that is envisaged in Article 1845 of the Civil Code. After lapse of 10 years from the formation of the contract, the defect is presumed to have been cleansed by operation of the law.

In light of the brief discussion in the sections above, words such as "of no effect", "null" or "non-existent" should be taken to mean "void". And the phrase "may be invalidated" should have been consistently used in the Civil Code to mean "voidable". However, the Code mingles void agreements (due to grounds of defective object and form) with voidable contracts (defective due to lessened capacity or defective consent) as a result of which ambiguities and contradictions arise. This apparent contradiction between Article

\footnotetext{
${ }^{72}$ At least Art. 1676 of the Civil Code authorizes the application of provisions of contract for
} performance of obligations arising from non-contractual relations too. 
1808 (2) and Articles 1714, 1715, 1716, $1720 \mathrm{ff}$ can be resolved only if the phrase "... may be invalidated ...." in Article 1808 (2) is interpreted as"...may be declared void..." However, this remains to be a temporary solution until the nature and effect of void agreements vis-à-vis voidable contracts are distinctly and unambiguously articulated by legislative action, or at least until the problem is addressed through a case decided by the Cassation Division of the Federal Supreme Court so that its analysis and ruling can be binding in the interpretation of similar legal issues which involve Article 1802/2 of the Civil Code. 